Панајотис Асимопулос

Војна Академија Грчке $811.14^{\prime} 06^{\prime} 367.632$

$811.163 .41^{\prime} 367.632$

$811.161 .1^{\prime} 367.632$

https://doi.org/10.18485/filkult.2016.2.ch16

\title{
СЕМАНТИЧКИ И СИНТАКСИЧКИ ИДЕНТИТЕТ УСЛОВНИХ КЛАУЗА У МОДЕРНОМ ГРЧКОМ, РУСКОМ И СРПСКОМ ЈЕЗИКУ
}

\section{Сажетак}

Опширан приступ сложеном феномену услова дијахронично презентира се као омиљена тема значајних синтаксичара, чињеница која указује на његову оригиналну продорност у сваку духовну манифестацију, али углавном и његов доминантан положај у теоретским наукама (когнитивна психологија, вештачка интелигенција, филозофија ума, лингвистика).

Упркос заједничкој тематској осовини релевантне интердисциплинарне студије заснивају се на постизању различитих стремљених циљева, док се изведени закључци сматрају детерминистичким резултатом аутономног, интелектуалног процеса. Осим тога примењене методолошке праксе, и употребљена база података врше каталитички утицај на обликовање истраживања, али и на холистичко схватање испитаног појма. С друге стране изложене дидференције не успевају да пониште општеприхваћену констатацију да је погодбеност нераскидиво испреплетена са концептуланом позадином људског постојања. Конкретније урођена тежња свих нас да усвајамо алтернативне ситуације на основу непотпуних информација одражава се на идеалну, често трансценденталну корелацију доживљених параметара научних знања.

У овом раду првенствено покушавамо да извршимо концизно разјашњење теоријског оквира који се односи на семантичку специфичности и синтаксичку јединственост кондиционалних реченица у новогрчком, у руском, и у српском језику. Након тога путем паралелног распоређења одабраних примера из оригиналног текста легендарног романа Дидо Сотириоу „Земља натопљена крвљу“ и њихових преводних еквивалената у оба словенска језика постиже се представљања основних сличности, али и њихових суштинских одступања.

Кључне речи: условне клаузе, значење, синтакса, грчки, руски, српски 


\section{1. Уводне напомене}

С обзиром да је саставна оријентација кондиционалности аутентична когнитивнапојавареиспитивањеалтернативнихситуацијадетерминистички јавља се као општељудска тенденција. Сходно томе условне реченице су језичка средства која успешно илуструју нејасне односе непредвидљиве стварности и диференциране нијансе евентуалности. ${ }^{1}$

\section{2. Осврт на дефиницију погодбених реченица}

Са два елементарна гледишта традиционални граматичари прилазе правом тумачењу појма „условна клауза“. Складно томе (а) осврћу се на кондиционалну коњуњкцију или (б) фокусирају на међуреченичне релације: (а.) Dancygier (1998: 1) прихвативши термин "conditional“ тврди: „соmplex sentences, composed of the main clause (sometimes also called q or the apodosis) and a subordinate clause ( $p$ or the protasis)“ и (а $\left.\mathrm{i}_{\mathrm{ii}}\right)$ Bennett (2003: 4) сматра да је кондиционална реченица бинаран „,item expressible in a sentence of the form «If [sentence $A$ ], then [sentence C]", the effect of the whole being to apply a binary operator to propositions expressed by those two contained sentences" која се састоји од главне клаузе и од зависне компоненте уведене са погодбеним везником, док (б) Hacking (1998: 1) наводи да је условна веза „between two events is one in which the realization of one event is dependent upon or conditioned by another" и ( $\left.\sigma_{i j}\right)$ Bhatt and Pancheva (2006: 638) исказују да условне структуре „in general terms, with the proposition expressed by the antecedent clause specifying the (modal) circumstances in which the proposition expressed by the main clause is true".

\section{3. Основни подаци кондиционалних клауза у грчком језику}

Међу темељне особине условних реченица чији се идентитет илуструје изразито помоћу подударајућих закључака грчких теоретичара спадају:

$1 \quad$ Traugott et al. 2009: 3 


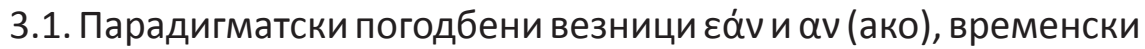

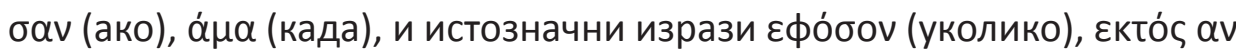

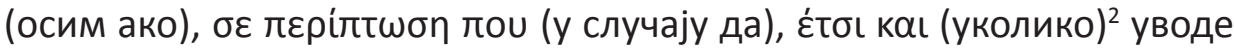
подређену реченицу или протазуз

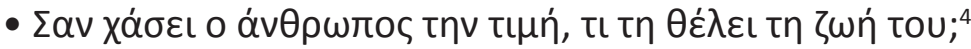

* Ако човек изгуби своју част, што му живот значи?

3.2. Четири поткатегорије условних реченица ${ }^{5}$ које указују на:

(i) реалне

Кад је садржај аподозе истинит, показује објективну чињеницу од које зависи остварење смисла протазе:

„Av + индикатив времена [- имперфект / плусквамперфект] $\Rightarrow$ сваки начин"

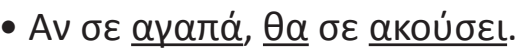

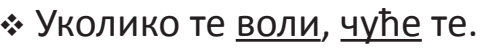

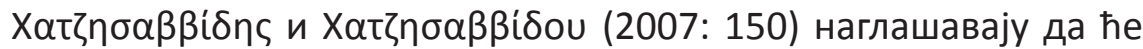
се сигурно остварити радња означена у зависној клаузи:

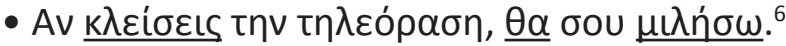

* Ако угасиш телевизор, причаћу ти.

(ii) иреалне

Претпостављена радња није се остварила нити може да се оствари, док представљају се субјективно мишљење или лични став говорећег лица без обзира на могућност реализације:

„Av + индикатив имперфекта $\Rightarrow \theta \alpha(б и x)+$ индикатив имперфекта“"

2 Углавном има нијансу претње (Holton et al. 2012²: 553):

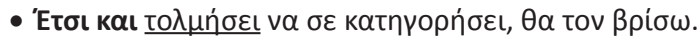

* If he dares accuse you I will give him a piece of my mind.

3 Holton et al. (2004: 223-224) додаје: „A protasis may occasionally be introduced by the subjunctive particle $\boldsymbol{v} \alpha$, in which case the verb is negated by $\mu \eta v^{\prime \prime}$ :

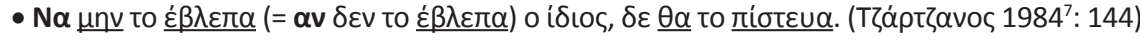

* Да га сам нисам видео, не бих поверовао.

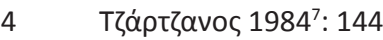

5 Осим условних клауза и глаголски прилог садашњи функциоише као адвербијална

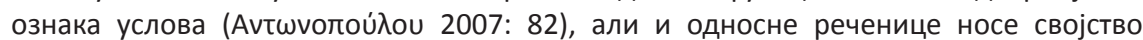

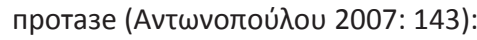

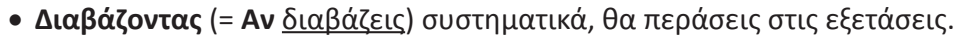

* Учећи (= Ако учиш) систематички, положићеш испите.

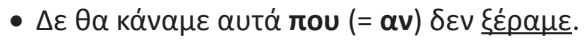

* Не бисмо учинили све то (= да) не знамо.

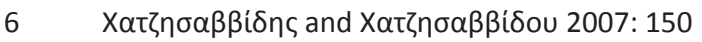

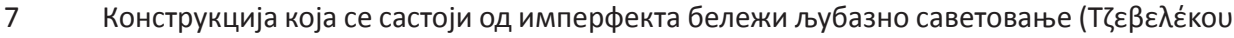
et al. 2007: 203): 
„Av + индикатив плусквамперфекта $\Rightarrow \theta \alpha(б и x)+$ индикатив плусквамперфекта“

„Av + индикатив имперфекта $\Rightarrow \theta \alpha(б и x)+$ индикатив плусквамперфекта“

„Av + индикатив плусквамперфекта $\Rightarrow \theta \alpha(б и x)+$ индикатив имперфекта“"

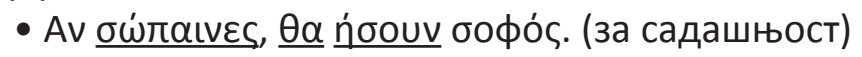

* Да си ћутао био би мудар.

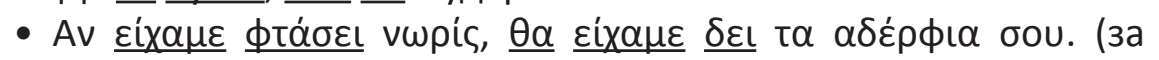
прошлост)

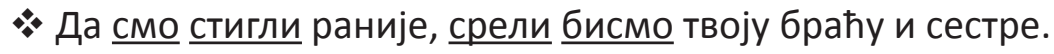

(iii) итеративне

Протаза имплицира понављајућу делатност:

(a) „Av + индикатив имперфекта $\Rightarrow$ индикатив имперфекта“

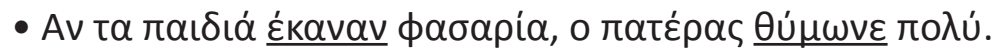

* Ако у деца галамила, отац љутио се много.

(б) „Av + коњунктив аориста / перфекта $\Rightarrow$ индикатив презента“

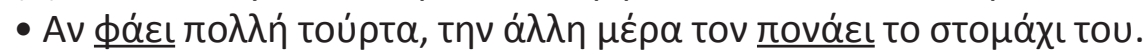

* Ако једе много торте, следећег дана боли га желудац.

(iv) потенцијалне

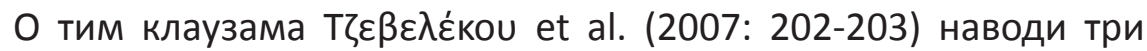
комбинације:

(a) „Av + индикатив презента $\Rightarrow$ презент / футур / императив / коњунктив“

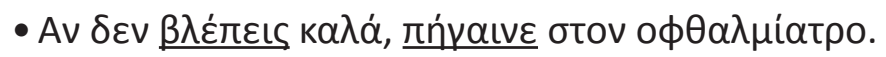

* Ако не видиш добро, иди код очног лекара.

(б) „Av + индикатив перфекта $\Rightarrow$ футур / императив / коњунктив“

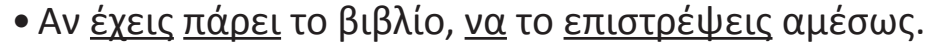

- Ако си узео књигу, врати је одмах.

(в) „Av + коњунктив аориста / перфекта $\Rightarrow$ индикатив футура / императив"

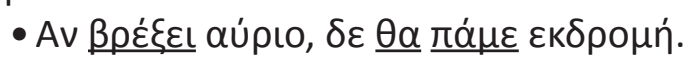

* Ако сутра падне киша, нећемо ићи на излет.

3.3. Употреба директне упитне реченице као емфатично средство услова:

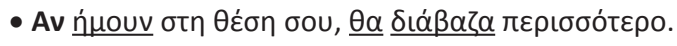

* Да сам на твом месту, учио бux више. 


\section{Филологија културе}

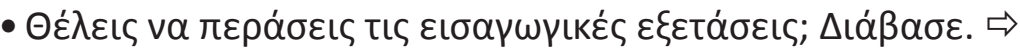

Av $\underline{\theta \varepsilon ́ \lambda \varepsilon เ \varsigma ~ v \alpha ~ \pi \varepsilon \rho \alpha ́ \sigma \varepsilon เ \varsigma ~ \tau \iota \varsigma ~ \varepsilon เ \sigma \alpha ү \omega ү เ к \varepsilon ́ \varsigma ~ \varepsilon \xi \varepsilon \tau \alpha ́ \sigma \varepsilon เ \varsigma, ~ \delta ı \alpha ́ ß \alpha \sigma \varepsilon . ~}$

* Хоћеш ли наћи бољи посао? Потруди се.

Уколико хоћеш наћи бољи посао, потруди се.

3.4. Увођење двочланих кондиционалних клауза са

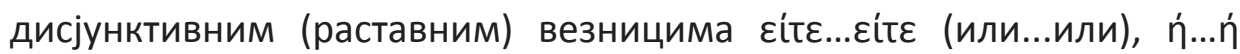
(или...или) $)^{8}$ :

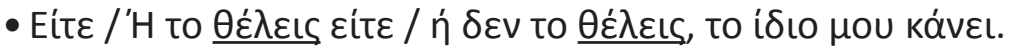

* Хоћеш ли га или не (Хоћеш-нећеш), свеједно ми је.

\section{4. Језичка средства условних односа у руском језику}

Алла Величко (20093: 299) кондиционалне релације уврстава међу врсте „таких отношений обусловленности, когда соединены две ситуации, из которыходна поставлена взависимость отдругой“.

4.1. Базичне зависне реченичне структуре ${ }^{9}$ са погодбеном подлогом уводе се везницима если (ако), если бы (ако би), раз (уколико), когда (када), и еквивалентним фразама [только] в случае если ([само] у случају да), [лишь] в [тот] случае если ([само] у случају да), при условии если (под условом да), при [тот] условии если (једино под условом да), коль скоро (ако):

- Вы можете пользоваться библиотекой института при условии, если в конце года вернёте все книги.

* Ви можете користити библиотеку Института под условом да на крају године вратите све књиге.

Углавном бележе се следеће поткатегорије услова:

(i) реалан (фактуалан)

Уз индикативне или инфинитивне облике у подређеној клаузи, везници если (ако), раз (уколико), когда (када) са презентом (прошлим

Holton et al. $2012^{2}: 553$

Условност изражавају глаголски прилози који значе једнократност, итеративност, процесност (Величко 20093: 305):

- Совершив (= если совершите) автобусную экскурсию, вы познакомитесь с историческими местами города.

- Учинивши (= ако учините) аутобуску екскурзију, упознаћете се са историјским местима града. 
или будућим вреемном или инфинитивом) протаза бележи узајамну зависност претпоставке и резултата:

(а) који се одвијају само једном ${ }^{10}$ :

- Раз ты просишь, то я подожду.

- Уколико ти то тражиш, онда сачекаћу.

- Если ты голоден, разогрей суп.

* Ако сити гладан, загреј суп.

(б) чији је карактер итеративни, док бележи обичност. У том случају најчешће глаголски облици припадају истом времену и несвршеног су вида ${ }^{11}$ :

- Если его спрашивают о чём-либо, то он всегда отвечает.

* Ако (Кад год) га питају о било чему, он увек одговара.

(в) који се односе на сумњу и изражавају се упитним обликом главне клаузе:

- Если ты не был там, то почему ты это скрываешь?

* Ако ти ниси био тамо, онда зашто то кријеш?

(г) који помоћу реторичког питања у аподози означавају сигурност или тачност:

- Как можно о нём говорить, если мы ничего не знаем о нём! о њему!

* Како је могуће да причамо о њему, уколико ништа не знамо

(д) који се због безвременског смисла појављују у афоризмима, пословицама ${ }^{12}$ :

- Если щи хороши, другой пищи не ищи.

* Ако је супа од купуса добра, другу храну не тражи.

(ii) потенцијалан (евентуалан, могући)

Подређене клаузе излажу догађаје који претходе ситуацијама показаним у главном делу хипотетичког периода ${ }^{13}$. У својству предиката функционише инфинитив глагола свршеног вида или прво лице множине ${ }^{14}$ :

10 Шелякин 2001: 266-267

11 Величко 20093: 300

12 Величко 2009: 301

13 Изузимају се аподозе са речима значит (значи), следовательно (стога), стало быть (према томе):

- Если он пришёл, то, значит, он получил записку. (Шелякин 2001: 266)

* Уколико је он дошао, онда значи, примио је поруку. 
- Если принять (мы примем) за единицу количество тепла, выделяемого за одну минуту, то вычисление значительно упростится.

* Ако као јединицу узмемо количину топлоте која се проиводи у једном минуту, онда рачунање је значајно једноставније.

Шелякин (2001: 265) наводи да „предикаты могут употребляться во всех временных, модальныхи видовых формах и их соотношениях":

- Если он вернулся из командировки, то он придёт на работу.

* Уколико cе он вратио са пословног пута, онда доћи ће на посао.

(iii) временски

Та врста подцртава репродукован однос ситуација на максималном нивоу који ствара уопштен спектар апсолутне законитости ${ }^{15}$. Везник если (ако) замењује се темпоралним везником когда (када), и то уз глаголе у презенту, будућем времену, перфекту или са кратким облицима (глаголског) придева:

- В том случае, если (когда) известны координаты точки, можно найти её положение в пространстве.

* Само у случају да су нам познате координате тачке, можемо наћи њено место у простору.

(iv) нереалан (иреалан)

Протаза у коњунктиву представља очекиван резултат радње обликоване у надређеној клаузи која је такође у коњунктиву ${ }^{16}$, и уводи се са везницима если бы (ако би), кабы (уколико би), ежели бы (ако би), как бы (како би):

- Если бы на Луну не действовала сила земного притяжения, (то) она унеслась бы в просторы Вселенной.

* Да на Месец није деловала сила Земљине гравитације, онда он не би продро у пространство свемира.

4.2. Употребом конструкција ли...ли, ли...или, ли...ли...или

15 Шведова и др. (1980: 571) фокусира на семантичку еквивалентност временских условних клауза са односним реченицама:

- Художник умирает, если он повторяется Художник, который повторяется, умирает.

* Уметник умире, ако се понавља Уметник који се понавља умире.

16 У колоквијалном и журналистичком говору јављају се императивни или инфинитивни облици који се користе уместо коњунктива (Величко 20093: 305-306):

- Будь / если бы быть (= если бы была) Оля внимательнее, она не сделала бы этой ошибки.

* Да је Оља била пажљивија, не би учинила ту грешку. 
остварење радње изложенеу главној реченици сматра се изводљивим под било којим условима ${ }^{17}$ :

- Не сдают ли студенты сессию, возникают ли проблемы с преподавателями, декан должен всегда быть в курсе событий.

* Буду ли студенти полагали испит, буду ли настали проблеми са наставницима, декан мора да је увек у току догађаја.

4.3. Често у аподози глагол речце так (тако), тогда (тада) и тут (тада) носе временско значење; то (тада), то значит (тада значи), следовательно (стога) потврђују емфатичну нијансу условнопоследичности:

- Если директор знает экономику, то он успешно будет решать проблемы.

Уколико шеф зна економику, онда ће успешно решавати проблеме.

4.4. Предлошко-падежне конструкције без / в случае + род. пад., при + предл. пад., и безвезничне структуре бележе условност (Величко 20093: 304-305, 308):

- При необходимости ( $\Rightarrow$ если необходимо) вы можете брать книги в библиотеке.

* По потреби ( $\Rightarrow$ ако је потребно) у библиотеци можете позајмити књиге.

- Неподготовился ( $\Rightarrow$ если не подготовился) кзанятиям-неходи вуниверситет.

$\Rightarrow$ Ако се ниси спремио за часове, немој ићи у универзитет.

4.5. Уводне комбинације у својству протаза састављају се од везника если и од ${ }^{18}$ (а) личних глаголских облика: если не ошибаюсь (ако се не варам); (б) модалних речи: если хотите (ако хоћете), если можно (ако може); (в) инфинитивних структура: если правду сказать (ако кажем истину):

- Если можно купите мне словарь.

* Ако може купите ми речник.

17 Величко 2009: 303

18 Величко 2009³ 309 


\section{5. Уведене погодбене реченице српског језика}

Сажетом дефиницијом Симић ${ }^{19}$ тврди да „условном зависном реченицом означава се претпостављени услов за остварење садржаја управне реченице“.

5.1. По нијанси остварљивости радње исказане аподозом српски теоретичари бележе тродимензионалну класификацију уведених ${ }^{20}$ условних реченица на:

(i) реалне

Уз везнике ако, уколико ${ }^{21}$ и са ређом у колоквијалном говору речцом ли обистињавају свој назив. Указују на велику могућност остварења условљене радње првенствено у будућности или у садашњости, а уз мању фреквенцију у прошлости. Значи да упркос томе да је исход описаног услова неизвестан, може се очекивати. У оба дела хипотетиког периода има индикативних структура, мада аподоза изражава се и заповедним начином. Употребљавају се презент за садашњост, перфекат за прошлост и презент или футур II за будући услов: ${ }^{22}$

- Ако / Уколико нађеш (будеш нашао) карту, идеш (ићи ћеш / иди) на концерт.

19 Симић 2002: 93

20 Адвербијалну функцију услова носе и структуре без везника (Мразовић и Вукадиновић 1990: 533-534):

(i) глаголски придев трпни:

- Благо / Искрено / Поштено речено наши студенти су разборити и вредни $\Rightarrow$

- Ако говоримо благо / искрено / поштено наши студенти су разборити и вредни.

(ii) глаголски прилог садашњи:

- Разматрајући пажљиво одбрану противника, јако лако ћемо га победити. $\Rightarrow$

- Ако разматрамо пажљиво одбрану противника, јако лако ћемо га победити. (iіi) глаголски прилог прошли:

- Узевши у обзир број незапослених, розачараћемо се. $\Rightarrow$

* Ако узмемо у обзир број незапослених, розачараћемо се.

(iv) заповедни начин на почетку клаузе:

- Усуди се да ми сметаш, па покајаћеш се. $\Rightarrow$

* Ако се усудиш да ми сметаш, па покајаћеш се.

21 По Клајну (2004: 252) везник уколико означава мању вероватноћу остварења описане радње, а по Мразовић и Вукадиновић (1990: 532) у значајној мери изражава будућност.

22 Станојчић и Поповић (19996: 321, напомена 2) наглашавају да је употреба потенцијала могућа, с тим што показује се мала вероватноћа остваривања услова:

- Ако би ме неко тражио, зови ме! 
Нађеш ли (Будеш ли нашао) карту, идеш (ићи ћеш / иди) на концерт.

- Ако / Уколико је био заузет, није звао шефа.

(ii) потенцијалне (могуће)

Сајасно хипотетичним карактером и без обележјапрогнозирања коначног резултата формирају се са везницима кад(а), ако, уколико који се удружују са потенцијалом I и II, а бележе могуће остварење исказаног условног значења. Претпоставка сматра се вероватном, актуелном или замишљеном: ${ }^{23}$

- Кад / Ако / Уколико би лутка знала шити, могла 뜨 ми шваља бити.

Вреди споменути да исти значењски оквир има уводна реченица која почиње са везником да, док је глагол свршеног вида у презенту: ${ }^{24}$

- Све бих дао да ме она воли (= кад би ме она волела).

(iii ${ }_{a}$ иреалне (нереалне) за садашњост

Изричу немогући услов који није усклађен са стварности, јер ради се о претпоставци „која је контрафактуална“, тј. супротна стварним чињеницама“. 25 Те зависносложене реченице уводе се са структурама „да + презент несвршеног вида“ или „кад + потенцијал I“, а у главној реченици глагол је у „потенцијалу I“:

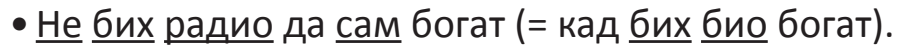

(iii ${ }_{6}$ иреалне за прошлост

Означавају да нису постојали прави услови да се изврши радња главне реченице. У зависној клаузи налази се структура „да + перфект (не)свршеног вида“, а у надређеној „потенцијал II“:

- Да Њутн није изводио огледе, не би открио закон гравитације.

5.2. Међутим под утицајем критерија временског периода на који сеуслови односе кондиционалне реченице које функционишукао прилошке одредбе за услов разврставају се на четири поткатегорије (будући, садашњи, прошли, свевременски), и то у зависности од степена остварљивости радње: ${ }^{26}$

(i) реалне:

\footnotetext{
23 Станојчић и Поповић 19996: 320

24 Клајн 2004: 253

25 Станојчић и Поповић 19996: 320

26 Станојчић и Поповић 19996: 320-322 
(1) будуће „ако / уколико + презент / футур други“:

- Ако / Уколико падне (= буде пала) киша, узећеш ( = узми / узимаш) такси.

(2) садашње „ако / уколико + презент / резултативни перфект“:

- Ако / Уколико отац прими (= је отац примио) плату, купиће нам играчке.

(3) свевременске „ако / уколико / кад + квалификативни (описни) презент“:

- Ако / Уколико / Кад се температура спусти на $0^{\circ} \mathrm{C}$, вода почиње да се смрзава. ${ }^{27}$

(ii) потенцијалне:

(1) будуће $\Rightarrow$ „кад + потенцијал / да + презент свршеног вида“:

- Било би нам лепо кад бисте дошли (= да дођете) у суботу.

(iii) иреалне за садашњост:

(1) садашње $\Rightarrow$ „кад + потенцијал / да + презент несвршеног вида“:

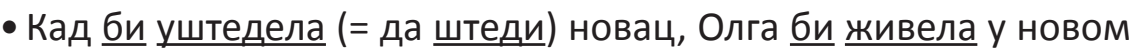
стану.

(iii $\left.{ }_{6}\right)$ иреалне за прошлост ${ }^{28}$ :

(1) прошле „да + перфект“:

- Да се дао интересантан филм, свратио бих у биоскоп.

5.3. Погодбени везник да и временски кад(а) манифестују

27 Мразовић и Вукадиновић 1990: 529

28 Према Мразовић - Вукадиновић (1990: 532 - 533 у српском има условних реченица које значе:

(i) рестриктивност (ограничава се смисао исказане погодбене ситуације):

(1) будуће $\Rightarrow$ „само + ако / уколико + презент / футур II / потенцијал I“:

- Само ако / уколико имам услове да усвојим маче, написаћу Вам.

(2) садашње $\Rightarrow$ „, само + ако + презент / футур II / потенцијал I“:

- Само ако би могла да освајаш трофеје, прихвати ту дарежљиву понуду.

(ii) мотивисање (уз глаголе говорења или мишљења врши се потицање на активно остварење датог услова):

(1) садашње / прошле / будуће $\Rightarrow$ „ако + презент / перфект / футур I и II / потенцијал | и ||":

- Ако ти је сестра марљива и успешна, зашто не имитираш њен начин рада?

(iii) подразумевање (јасан параметар без директног навођења):

(1) садашње / прошле / будуће $\Rightarrow$ „ако + презент / перфект / футур I и II / потенцијал

I и ||":

- Ако се не варам, наша колегиница Тања је дошла на свадбу.

- Замолио бих те ако би била љубазна да ми пошаљеш слике из Италије. 
говорниково знање о свом односу са реализацијом радње назначене глаголским предикатом:

- Да су знали да сте код куће, сигурно би дошли.

- Кад бисмо манје причали на часу, више бисмо научили.

С друге стране субјунктори ако и уколико указују на евентуално реалне околности, а бележе незнање носилаца комуникацијског чина о условљеном остварења радње саопштене у главној реченици: ${ }^{29}$

- Ако има (= не знамо да ли има) места, сутра идемо на фудбалску утакмицу.

-Уколико cy књиге распродате (= не знамо тај факат), питај библиотекара.

\section{6. Анализа}

Без сумње теоретски приступ изабраним кондиционалним структурама у три испитана језика омогућује суштинском проучавању њихових темељних обележја. Према томе у овом раду стремили смо ка паралелном презентирању карактеристичних случајева изведених из грчког романа Дидо Сотириу „Земља натопљена крвљу“ (340 страница), а из надахнутих отелотворења у руском од Александра Сенкевича (240 страница), и у српском преводу (294 странице) од Гаге Росић. Укупан број пронађених примера је 50 који се односе на 13 посебниих верзија условних клауза. Наишли смо на четворочлану поделу условних клауза: (а) реалне у 20 конструкција; (б) иреалне у 14 хипотетичких периода; (в) итеративне у 8 случајева; (г) потенцијалне у 8 примера. Том приликом наглашавамо да је у српском преводу (односно прошло време у руском) перфект несвршеног вида еквивалентан имперфекту, док је у оба словенска језика перфект свршеног вида истозначан аористу и плуперфекту:

\section{1. Реалност: 20 примера}

\subsection{1. Индикатив $\Leftrightarrow$ Индикатив}

Руске и српске условне реченице изражавају се сасвим једнако грчким клаузама, односно помоћу индикативних форми истих времена:

29 Мразовић и Вукадиновић 1990: 529-530 
6.1.1.1. „Av + Индикатив Презента $\Leftrightarrow$ Индикатив Презента“ (4 примера)

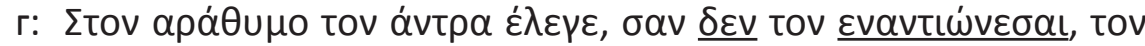

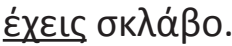

p: «Если вспыльчивому мужу не противиться, он всегда будет твоим рабом».

с: Уколико се не супротстављаш разбеснелом човеку, држиш га у својој власти.

6.1.1.2. „Av + Индикатив Презента $\Leftrightarrow$ Индикатив Имперфекта“ (1 пример)

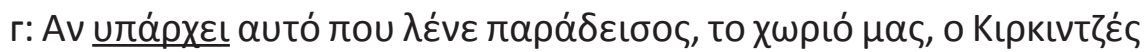

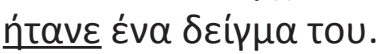

p: Если существует рай, то наша деревня Кыркындже была его подобием на земле.

с: Ако постоји рај, наше село Киркицес 르 био његов живи пример.

6.1.1.3. „Av + Индикатив Аориста $\Leftrightarrow$ Индикатив Презента“ (1 пример)

г: av

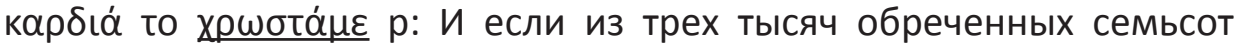
человек все-таки остались в живых, обязаны они этим Шюкрюэфенди.

c: ако је од три хиљаде колико нас је било преживело седамсто војника, онда ово дугујемо племенитом Сукри-ефендији. пример)

6.1.1.4. „Av + Индикатив Аориста $\Leftrightarrow$ Индикатив Аориста“ (1

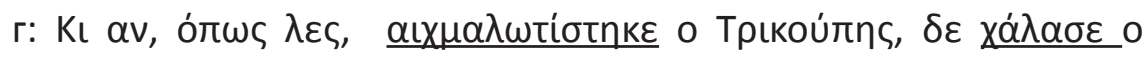

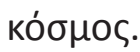

p: Но если даже Трикупис взят в плен, как ты говоришь, 르 все пропало!

с: Па чак да уㅡ и заробили Трикуписа, као што ти кажеш, није пропао свет!

6.1.1.5. „Av + Индикатив Презента $\Leftrightarrow$ Индикатив Футура“ (3 примера)

Преводни еквиваленти грчким конструкцијама чија је синтаксичка улога ознака реалности поистовећују се у аподози 
(облици футура свршеног вида). Ипак у протази у српском језику остварују се помоћу:

(а) презента (као у руском):

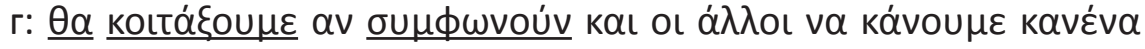

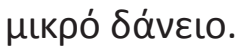

р: мы постараемся - если все согласятся - занять небольшую сумму.

c: гледаћемо ако се и остали слажу да од неког узмемо неки мали зајам.

(b) футура другог:

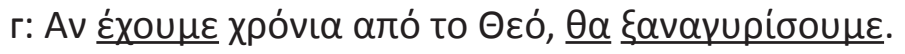

p: Если Богу будет угодно, мы вернёмся.

c: Ако Бог буде хтео вратићемо еㅡ ми.

6.1.2. Индикатив $\Leftrightarrow$ Императив

У руском и у српском преводу имперфективни облици заповедног начина су везани за презентски императив, а свршени за аористски у грчком тексту:

6.1.2.1. „Av + Индикатив Презента $\Leftrightarrow$ Императив Презента“ (7 примера)

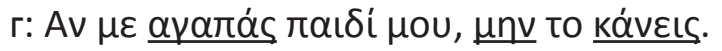

р: Если ты любишь меня, сынок, не делай этого.

с: Ако ме волиш, дете моје, не чини то.

6.1.2.2. „Av + Индикатив Аориста Императив Аориста“ (3 примера)

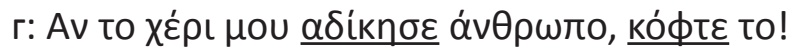

p: Если моя рука была несправедлива к человеку - отруби её!

с: Ако ли се рука огрешила о човека, одсеци је!

6.2. Иреалност: 14 примера

6.2.1. Индикатив $\Leftrightarrow$ Индикатив

За примере који су уоригиналној верзији изражени индикативом у руском (и у аподози и у протази) као истозначне структуре употребљавају се облици коњунктива свршеног вида. Међутим дотичан синтаксички оквир у српском бележи се са индикативом (a) перфекта или (b) презента перфективних глагола у подређеној 


\section{Филологија културе}

реченици, а са потенцијалом или футуром у главној:

6.2.1.1. „Av + Индикатив Имперфекта $\Leftrightarrow \theta \alpha+$ Индикатив Имперфекта"

(12 примера)

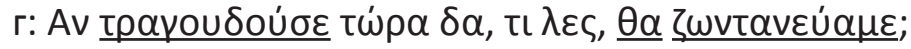

p: Если бы она спела сейчас, мы бы, пожалуй, ожили!

с: Кад би сада запевала, шта кажеш, мислиш да бисмо оживели?

6.2.1.2. „Av + Индикатив Плуперфекта $\Leftrightarrow \theta \alpha+$ Индикатив Имперфекта“"

(2 примера)

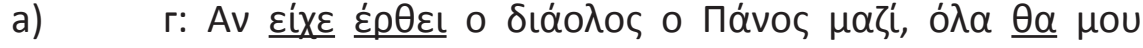

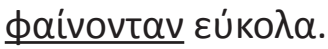

р: Если бы этот чертов Панос поплыл со мной, было бы всё-таки легче.

c: Да је са мном био онај ђаволски Панос, све би ми било лакше.

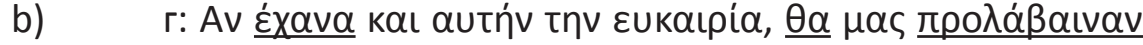
ol Toúрко

р: Если бы я упустил этот случай, турки нагнали бы меня с Дросакисом.

с: Ако изгубим ову прилику, Турци ће нас стићи.

\section{3. Итеративност: 8 примера}

6.3.1. Индикатив $\Leftrightarrow$ Индикатив

Значењска идентификација итеративног услова у грчком тексту постиже се индикативом у руском, а потенцијалом у српском преводу:

6.3.1.1. „Av + Индикатив Имперфекта $\Leftrightarrow$ Индикатив Имперфекта“ (5 примера)

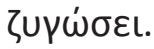

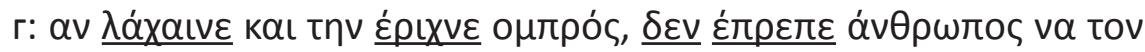

p: Если кисточка нависала ему на лицо, то лучше было с ним не заговаривать.

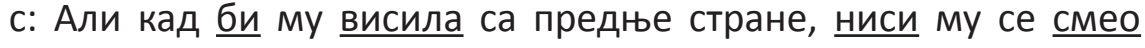
приближити.

\subsection{2. Коњунктив $\Leftrightarrow$ Индикатив}

Коњунктивне структуре које се бележе у грчким примерима замењују индикативни облици у руским и српским преводним еквивалентима: 
6.3.2.1. „Av + Коњунктив Аориста $\Leftrightarrow$ Индикатив Презента“ (3 примера)

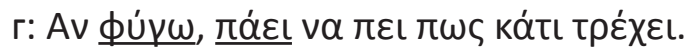

p: Если же меня не окажется на месте, значит, что-то случилось.

с: Ако ме нема, значи да се нешто дешава.

6.4. Потенцијалност (8 примера)

6.4.1. Коњунктив $\Leftrightarrow$ Индикатив

Грчки примери потенцијалногуслова који су узависној реченици означени коњунктивом аориста бивају изједначени формама индикатива перфективног презента. У главној клаузи примећујемо подударну употребу футура:

6.4.1.1. „Av + Коњунктив Аориста Индикатив Футура“ (7 примера)

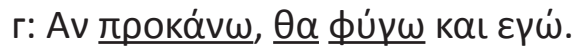

p: Если успею, то и я уйду.

с: Ако стигнем, и ја ұ за вама!

6.4.2. Коњунктив $\Leftrightarrow$ Императив

У оригиналном тексту, али и у преводним корпусима императивне форме илуструју резултат погодбене клаузе изражене коњунктивом аориста у грчком, и индикативом свршеног презента у руском и српском:

6.4.2.1. „Av + Коњунктив Аориста Императив“ (1 пример)

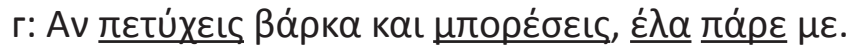

р: Если тебе попадется лодка и будет возможность, приезжай за мной.

с: Ако ти пође за руком да нађеш неки чамац, дођи по мене.

\section{7. Закључна разматрања}

На темељу спроведене анализе 50 оригиналних примера из грчког корпуса, ињихових преводнихеквивалената у руском исрпском језику представили смо најучесталије подударне и диференциране комбинације глаголских времена и начина у протазама и аподозама кондиционалних реченица. 
Заиста изненађују потврђена идентичност у синтаксичким обележјима, и настали полиедарски синкретизам између три испитана језика. Међутим посебнупажњувреди поклонити изразитим разликама. Конкретније:

(1) реалне: у протази презент у грчком замењује се футуром другим у српском (6.1.1. b)

(2) иреалне: у протази уместо грчког индикатива јавља се коњунктив у руском, и потенцијал у српском преводу (6.2.1.2. а); у аподози грчки имперфект или плуперфект исказују се руским коњунктивом (6.2.1.1.) и футуром (6.2.1.2. b)

(3) итеративне: индикатив је у протази оригинала истовредан потенцијалу у српском (6.3.1.1.), док у оба словенска језика грчком коњунктиву одговарају индикативне форме (6.3.2.1.)

(4) потенцијалне: грчки облици коњунктива односе се на индикатив у руским и српским еквивалентима (6.4.1.1.).

На нивоу прагматичке компетенције ти резултати представљају корисно градиво за лако превођење и конструктивно побољшање наставних стратегија.

\section{Литература}

Величко, Алла и др. Книга о грамматике. Русский язык как иностранный. 3 изд. Москва: Издательство Московского университета, 2009.

Клајн, Иван. Граматика српског језика за странце. Београд: Завод за уџбенике и наставна средства, 2004.

Константинова, Людмила и др. Грамматика русского языка. Часть ІІ. Учебное пособие по русскому языку для студентов-иностранцев II курса. Тула: Издательство Тульского государственного университета, 2007.

Мразовић, Павица и Зорица Вукадиновић. Граматика српскохрватског језика за странце. Сремски Карловци: Издавачка Књижарница Зорана Стојановића, Нови Сад: Добра Вест, 1990.

Симић, Радоје. Српска граматика 2, Синтакса. Београд: Научно друштво за неговање и проучавање српског језика. Никшић: ЈАСЕН, 2002.

Сотириу, Дидо. Земља натопљена крвљу. Прев. Гага Росић. Београд: Просвета, 2001.

Сотириу, Дидо. Земли, обагрённые кровью. Прев. Александр Сенкевич. Москва: Прогресс, 1964.

Станојчић, Живојин и Љиљана Поповић, Граматика српског језика. 6 изд. Београд: Завод за уџбенике и наставна средства, 1999. 
Шведова, Наталия и др., Русская грамматика, Том II, Синтаксис. Москва: Наука, 1980.

Шелякин, Михаил, Функциональная грамматика русского языка. Москва: Русский язык, 2001.

Bhatt, Rayesh and Roumyana Pancheva. „Conditionals." The Blackwell companion to syntax, vol. 1. Eds. Martin Everaert and Henk van Riemsdijk. Boston: Blackwell, 2006. 638-87.

Bennett, Jonathan. A philosophical guide to conditionals. Oxford: Clarendon Press, 2003.

Dansygier, Barbara. Conditionals and prediction: Time, knowledge, and causation in conditional constructions. Cambridge: Cambridge University Press, 1998.

Hacking, Jane. Coding the hypothetical: A comparative typology of Russian and Macedonian conditionals. Amsterdam: John Benjamins, 1998.

Holton, David, et al. Greek. An Essential Grammar of the Modern Language. London: Routledge, 2004.

Holton, David, et al. Greek. A Comprehensive Grammar. 2 ed. London: Routledge, 2012. Traugott, Elizabeth, et al. On conditionals. Cambridge: Cambridge University Press, 2009.

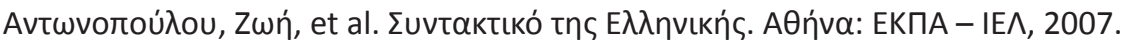

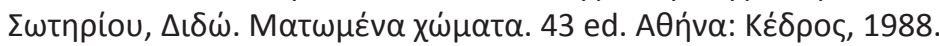

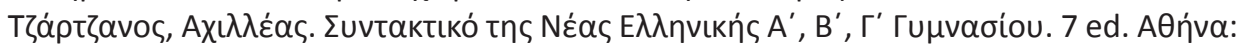
OE $\triangle B, 1984$.

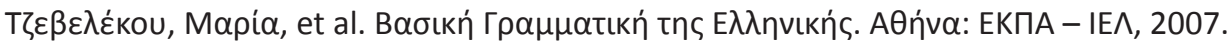

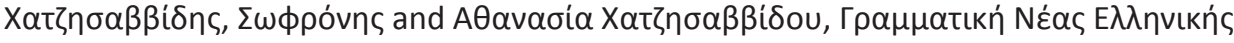

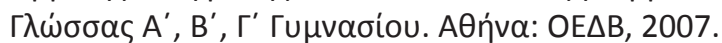

\section{Panagiotis Asimopoulos}

Hellenic Army Academy

\section{THE SEMANTIC AND SYNTACTIC IDENTITY OF THE CONDITIONAL CLAUSES IN MODERN GREEK, RUSSIAN AND SERBIAN LANGUAGE}

\section{Summary}

The thorough approach to the complicated phenomenon of the hypothesis diachronically seems to be a favorite topic of remarkable syntacticians, fact that reflects its authentic pervasiveness into any intellectual manifestation, but mainly the dominating presence at the theoretical studies (cognitive psychology, artificial intelligence, philosophy of mind, linguistics). 


\section{Филологија културе}

In spite of their common thematic axis the related interdisciplinary studies concerning the assumption are based on the achievement of different intended objectives, while the drawn conclusions are considered as a deterministic result of an autonomous, mental process. In parallel the applied methodological practices and the used database exert a catalytic influence on the research formation, as the holistic understanding of the examined concept. On the other hand the exposed antinomies fail to cancel the universally accepted ascertainment that the conditionality is inextricably interwoven with the perceptual background of the human existence. More specifically the people's inherent tendency to adopt alternative situations on the basis of incomplete information is incarnated in the ideal, often transcendental correlation of the perceived parameters of any scientific knowledge.

In this work at first we attempt a concise clarification of the theoretical framework related to the semantic specificity and the syntactic uniqueness of the conditionals in Modern Greek, Russian and Serbian language. Subsequently through the parallel presentation of selected examples excerpted from the original text of Dido Sotiriou's legendary novel "Farewell to Anatolia» and their translation equivalents in both Slavic languages we highlight the basic similarities and essential deviations concerning the conditional clauses.

Key words: conditionals, semantics, syntax, Greek, Russian, Serbian 